\title{
自生地において形成されるサギソウ種子の特性
}

\author{
高橋和彦 ${ }^{*}$ ・秦名俊光 ${ }^{2} \cdot$ 大谷久史 ${ }^{2} \cdot$ 石川 林 $^{2} \cdot$ 石橋久仁彦 ${ }^{2} \cdot$ 荻野崇義 $^{2} \cdot$ 荻原 $^{\text {勲 }^{3}}$ \\ ${ }^{1}$ 東京都立園芸高等学校 $158-8566$ 東京都世田谷区深沢 \\ 2 愛知県立新城東高等学校作手校舎 441-1423 愛知県新城市作手高里 \\ 3 東京農工大学農学部 183-8509 東京都府中市幸町
}

\section{Characteristics of Habenaria radiata (Thunb.) K. Spreng. Seed Formation in Natural Habitat}

\author{
Kazuhiko Takahashi ${ }^{1 *}$, Toshimitsu Hatana ${ }^{2}$, Hisashi Ohtani ${ }^{2}$, Hayashi Ishikawa ${ }^{2}$, \\ Kunihiko Ishibashi' ${ }^{2}$, Takayoshi Ogino ${ }^{2}$ and Isao Ogiwara ${ }^{3}$ \\ ${ }^{1}$ Tokyo Metropolitan Engei Senior High School, Setagaya, Tokyo 158-8566 \\ ${ }^{2}$ Aichi Prefectural Shinshiro-higashi Tsukude Senior High School, Shinshiro, Aichi 441-1423 \\ ${ }^{3}$ Faculty of Agriculture, Tokyo University of Agriculture and Technology, Fuchuu, Tokyo 183-8509
}

\begin{abstract}
In order to grow Habenaria radiata (Thunb.) K. Spreng. seedlings in their natural habitat, they must be pollinated by insects (natural crossing) and form numerous seeds. We investigated the rates of capsule formation and seed germination in $H$. radiata in a natural habitat in Aichi Prefecture. Seed capsule formation and the germination rate of the formed seeds in H. radiata individuals growing in their natural habitat were widely altered. Subsequent investigations of the factors affecting seed germination rates revealed that $H$. radiata germination was not affected by the nutrient status. The presence of relatively few $H$. radiata pollinators in the study area was considered to be responsible for the low pollination rate. In addition, the rates of seed capsule formation and germination varied markedly depending on the timing of pollination (days after anthesis: DAA), with the highest rates of capsule formation and germination observed when pollination occurred in the middle term of flowering at 4 to 5 DAA. These findings suggest that $H$. radiata flowers are the most susceptible to pollination at 4 to 5 DAA, and that pollination by insects during this period results in the formation of capsules containing the most viable seeds.
\end{abstract}

Key Words : insect, pollination, rates of capsule formation, rates of seed germination

キーワード：受粉, 結実率, 昆虫, 種子発芽率

\section{緒言}

ラン科植物は単子葉植物で最も進化した植物種である が，生育する環境に適応するために進化の過程で種は多様 に分化し，ラン科植物の種数は地球上で最も多く, $700 \sim 800$ 属 2 万〜 2 万 5000 種を数えるといわれる（唐澤，1996）. しかし，環境に過剰に適応して進化したことで，一方では 環境の変化に対応できる幅が狭くなったとも考えられる. そのため, 日本に自生するラン科植物の絶滅から準絶滅危 惧に該当する割合は約 74\%で，他科のそれ（約 30\%）に比 べて極端に高く（古川ら，2013）, ラン科植物は地球上で最 も絶滅しやすい植物種であるともいえる.

日本を代表する野生ランの一種であるサギソウも, 近年

2016 年 7 月 26 日 受付. 2016 年 9 月 21 日 受理.

本研究の一部は, 独立行政法人日本学術振興会平成 26 年度科 学研究費補助金（奨励研究）(課題番号：26925001）で行った.

* Corresponding author. E-mail: k-s-taka@agate.plala.or.jp
の環境の変化や乱獲により準絶滅危惧種に指定されてい る。サギソウが自生地で実生から生育するには，虫媒によ る受粉（以下，自然受粉といら）により多くの種子が形成 されること，またその種子がラン菌根菌（以下，ラン菌と いら）と共生して生育する環境条件に恵まれていることの 2つの条件が必要である。高橋ら（2012）はこれまで，自 生地に打けるサギソウの実生生育を促すために，当該自生 地のラン菌を接種したゲル被覆サギソウプロトコーム設置 法を開発して自生地に設置したところ，サギソウプロト コームの生存率は約 $76 \%$ に高まるとともに生育状況も良 好となり，この方法を用いた自生地復活の可能性が示唆さ れた。しかし，自生地に打けるサギソウの種子形成の状況 は明らかにされていない。

そこで，愛知県新城市内のあるサギソウ自生地を供試自 生地とし，自然受粉したサギソウのさく果結実株の割合と 種子発芽率を調査した。自生地で形成されるさく果結実株 の割合が高く, かつ形成された種子の発芽率が高ければ, 実生生育に有利である。しかし，さく果結実株の割合と種 
子発芽率が低ければ, 実生による繁殖が困難となり, 世代 交代が緩慢となるために，自生地の衰退は避けられないと 推察される. 本研究では, 供試自生地に打ける自然受粉に よるさく果結実株の割合と形成された種子の発芽率とを, 人工受粉によるそれと比較検討し，自生地に打いて形成さ れる種子の特性を明らかにしょらとした。

まず，実験 1 では供試自生地内の自然受粉区と人工受粉 区のさく果結実株率と種子発芽率を調査した。実験 2 では 実験 1 のさく果結実株率を検討するために, 供試自生地か らやや離孔た他の自生地（愛知県新城市）と東京都内の栽 培地（東京都世田谷区）で形成されたさく果結実株の割合 を比較した，実験 3 では実験 1 の種子発芽率を評価するた めに, 他の系統のサギソウ種子発芽率と比較した. さらに, サギンウの種子発芽率に影響する要因を探るために，実験 4 ではサギッウ株の栄養状態の違いによる種子発芽率の差 異を, 実験 5 では開花から受粉までの開花後日数がさく果 結実株の割合と種子発芽率に及ぼす影響を検討した。

\section{材料および方法}

\section{1. 自生地におけるさく果結実株率, 種子発芽率および実 生率 (実験 1)}

“作手” 系サギッウ自生地（愛知県新城市）の中から 1 か 所を適意に選び，供試自生地とした，当該自生地のサギy ウの開花が満開となった 2011 年の 8 月中旬と 2012 年の 8 月下旬扣よび 2015 年の 8 月上旬に, 開花するサギソウの 一部を無作為に 1 株 1 花ずつ人工受粉して株に目印を付し， 人工受粉区とした。 また同時に，人工受粉せずに放置した サギソウ開花株にも異なる目印を付し，自然受粉区とし た、サギソウの葉が黄化し始めた 10 月初旬〜中旬に，人 工受粉区抢よび自然受粉区のそれぞれの株に結実したさく 果を採取した。人工受粉区扣よび自然受粉区から採取した さく果株のらち，肥大しなかったさく果株を除き，結実し て肥大したさく果株の割合をさく果結実株率とした，結実 したさく果は表面を $70 \%$ エタノールで殺菌し, 室内の冷 暗所で保存して種子発芽率の実験に供した。また，採種し たさく果のらち, 虫害による被害が認められたさく果株の 割合についても調查した.

種子発芽率の調査に当たり, 種子の殺菌打よび播種は 高橋ら（2008）の方法と同様に行い，1さく果内の種子を $1 \mathrm{~cm}$ 角の滅菌ろ紙片 5 枚にそれぞれ $50 \sim 150$ 粒ずつ播種

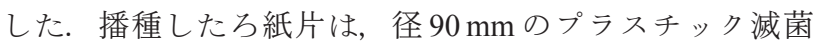
シャーレ内の培地に置床した. 培地は八イポネックス粉 末（6.5-6-19，（株）ハイポネックスジャパン） $3 \mathrm{~g} ・ \mathrm{~L}^{-1}$ 打 よびショ糖 $30 \mathrm{~g} ・ \mathrm{~L}^{-1}$ 溶液を $\mathrm{pH} 5.5 \sim 5.7$ 亿調整して寒天 $9 \mathrm{~g} ・ \mathrm{~L}^{-1}$ を加えた八イポネックス培地とし，オートクレー ブで $121^{\circ} \mathrm{C}, 15$ 分間滅菌して各シャーレに $20 \mathrm{~mL}$ ずつ分注 して用いた。

播種後は $24^{\circ} \mathrm{C}, 12$ 時間日長, $2000 \mathrm{Lx}$ の恒温室内で培養 した. 光源は白色光（ネオラインFL40SS，(株）東芝）を
用いた。 プロトコームから仮根が発生した状態を種子の発 芽とし，発芽率の調査は播種 3 週間後に行った.

\section{2. 異なるサギソウ生育地におけるさく果結実株率の差異 (実験 2)}

2011 年，2012 年拉よび 2015 年の 8 月中旬〜下旬に，供 試した “作手”系サギソウ自生地と, 供試自生地から約 $3 \mathrm{~km}$ 離孔た自生地 $\mathrm{A}$ （愛知県新城市）飞打いて, 開花す るすべてのサギソウ株に目印を付し，自然受粉により結実 したさく果株を10月初旬に採取し，さく果結実株率を調 查した。一方，2011年，2012 年抒よび 2015 年に自生地由 来の ‘作手’ 系サギソウ球根を 3 号のビニルポットに 1 球 ずつ水苔用土で植え付けて，東京都立園芸高等学校草花圃 場内（東京都世田谷区深沢）で無施肥栽培した。10月初 旬に自然受粉により結実したさく果を採取し，さく果結実 株率を調査した。

\section{3. サギソウの系統による種子発芽率の差異（実験 3)}

3 号ビニルポットにサギソウ球根を 1 球ずつ植え付けて 東京都立園芸高等学校草花围場内で施肥栽培した。用土に は水苔を用い，元肥として 1 ポット当たりマグアンプ K 小 粒（(株) ハイポネックスジャパン）を $0.5 \mathrm{~g}$ 施肥した。植 兄付けた球根は, 自生地由来の “作手” 系の他に, 市販の “青雲”系, ‘武蔵野’ 系抢よび ‘白河’ 系の各系統サギソウ 球根 30 球ずつとした。 2012 年 8 月上旬〜下旬にかけて開 花したそれぞれの株を系統内で互いに人工受粉した．受粉 時の開花後日数は考慮しなかった。形成されたさく果は 10 月中旬に採取した。採取したさく果のらち，上く肥大 して充実したさく果を適意に 3 個選び，種子発芽率の実験 に供した。種子発芽率の調査は実験 1 と同様に行った.

\section{4. サギソウ種子発芽率に及ぼす施肥の影響（実験 4）}

自生地由来の ‘作手” 系サギンウ球根を 1 球ずつ実験 3 と同様のポットと用土を用いて無施肥条件下で 2 年間栽培 した無施肥由来球根，打よび実験 3 と同様のポット，用土， 施肥条件下で 1 球ずつ 2 年間栽培した施肥由来球根を実験 に供試した。 2012 年 3 月に無施肥由来の球根と施肥由来 の球根をそれぞれ 1 球ずつ実験 3 と同様のポットと用土に 植え付け，無施肥区拈よび施肥区を設定した。無施肥区は 肥料を施さず，施肥区は用土に元肥として 1 ポット当たり マグアンプK小粒（(株) ハイポネックスジャパン）を $0.5 \mathrm{~g}$ 施肥した．各区ともに 30 ポットを東京都立園芸高等学校 の草花ガラス温室内で栽培した. 8 月上旬に開花したので, 無施肥区抢よび施肥区ともに第 2 花が開花し，第 3 花が開 花する前にそれぞれの処理区内で互いに第 2 花を人工受粉 した。 その後，第 1 花抒よび第 3 花以上は摘花し，第 2 花 の久残して実験に供した。10月中旬，各区に形成された さく果を採取し，このうち各区ともに比較的充実した 10 さやを種子発芽率の実験に供した。種子発芽率の調査は実 験 1 と同様に行った.

さらに，実験 1 の 2011 年に採取した人工受粉区のさく 果のらち，1株に 2 さく果が形成されていた 8 株を供試し 
て, 栄養条件が同じ 1 株に形成された複数のさく果の種子 発芽率に差があるかどらかを調査した，種子発芽率の調査 は実験 1 と同様に行った.

\section{5. 受粉時の開花日数ごとの種子発芽率（実験 5)}

2012 年，2013 年打よび 2015 年 3 月に実験 3 と同様に, ビニルポットに自生地由来の ‘作手’ 系サギソウ球根を 1 球ずつ植え付けて，実験 4 と同様の温室内で栽培した。用 土，元肥は実験 3 と同様とした. 各年とも 8 月上旬から開 花したので，第 1 花を対象に，開花から受粉までの日数を 変えて人工受粉した。開花から人工受粉までの日数は，開 花後 1〜3 日，4～5 日，6〜7日，8～9 日とした. 受粉に 用いた花粉は，開花後 $4 \sim 5$ 日目の花から採種して用いた. 受粉後, 第 2 花以上は摘花した. 結実したさく果は各年の 10 月中旬に採取した。 3 年間に採取したさく果のらちよく 肥大したさく果をさく果結実株率の調査に供し，2013 年 採取のさく果のらちよく肥大したさく果（各区 10 個）を 種子発芽率の調査に供した。種子発芽率の調査は実験 1 と 同様に行った.

\section{結 果}

\section{1. 自生地におけるさく果結実株率, 種子発芽率および実 生率 (実験 1)}

肥大したさく果が形成されたサギソウ株の割合をさく果 結実株率，さく果内の種子の発芽割合を種子発芽率で示 し, 結実株の割合と発芽割合の積の百分率を実生率として 第 1 表に示した。実生率は，供試自生地に扮いて生育する サギソウ 1 株当たりの実生生育可能な種子数の割合を示し ている.さく果の結実状況は，2011 年人工受粉区さく果
結実株のらち 8 株を除いて，1株に 1 さく果ずつ結実して いた.

2015 年，2012 年拈よび 2011 年の自然受粉区と人工受粉 区を比較すると，さく果結実株率抒よび被虫害さく果結実 株率は両区とも年次により変動が見られたが，両区間に差 は認められなかった。種子発芽率では2015年㐨よび 2011 年の自然受粉区と人工受粉区間に差は見られなかったが, 2012 年では自然受粉区は人工受粉区よりも高くなった. 一方，自然受粉区では年次による違いが認められたが，人 工受粉区では年次による違いは認められなかった。実生率 では 2011 年の自然受粉区と人工受粉区間に差が見られな かったが，2015年执よび2012年では自然受粉区よりも人 工受粉区で高くなった。一方，自然受粉区では 2015 年の 夕他年次よりも低くなったが，人工受粉区では年次による 違いが認められた。

\section{2. 異なるサギソウ生育地におけるさく果結実株率の差異 (実験 2)}

“作手’系サギソウの供試自生地と $3 \mathrm{~km}$ 離れたサギソウ 自生地 $\mathrm{A}$ 抢よび東京都内の栽培地に抢いて自然受粉によ りさく果が結実した株数扣よびさく果結実株率を第 2 表に 示した. いずれの試験区に扣いてもさく果結実株率は年次 により変動が認められたものの，東京都内の栽培地のさく 果結実株率は供試自生地拈よび自生地 $\mathrm{A}$ の結実株率より も高かった。な拝，東京都内の栽培地で形成されたさく 果には薬剤を散布したためか，被虫害さく果は見られな かった。

\section{3. サギソウの系統による種子発芽率の差異（実験 3）}

サギソウの系統ごとの種子発芽率を第 3 表に示した。 ‘作

第 1 表 ‘作手’系サギソウの自生地に打けるさく果結実率，種子発芽率，実生率扮よび被虫害さく果結実株率

\begin{tabular}{|c|c|c|c|c|c|c|c|c|}
\hline 調査年 & 受粉形態 & $\begin{array}{l}\text { 供試 } \\
\text { 株数 }\end{array}$ & $\begin{array}{c}\text { さく果 } \\
\text { 結実株数 }{ }^{\mathrm{z}}\end{array}$ & $\begin{array}{c}\text { さく果 } \\
\text { 結実株率y } \\
(\%) \\
(\%)\end{array}$ & $\begin{array}{c}\text { 種子 } \\
\text { 発芽率 x } \\
(\%)\end{array}$ & $\begin{array}{c}\text { 実生率 }{ }^{\mathrm{w}} \\
(\%)\end{array}$ & $\begin{array}{c}\text { 被虫害 } \\
\text { さく果 } \\
\text { 結実株数 }\end{array}$ & $\begin{array}{c}\text { 被虫害 } \\
\text { さく果 } \\
\text { 結実株率 } \\
(\%)\end{array}$ \\
\hline \multirow{2}{*}{2015} & 自然受粉 & 117 & 10 & 8.5 & $42.7 \pm 11.4^{\mathrm{t}} \mathrm{b}^{\mathrm{s}}$ & $3.6 \pm 1.0 \mathrm{a}$ & 0 & 0 \\
\hline & 人工受粉 & 53 & 26 & 49.1 & $56.5 \pm 8.3 \mathrm{bc}$ & $27.7 \pm 4.1 \mathrm{~d}$ & 1 & 3.8 \\
\hline \multirow{2}{*}{2012} & 自然受粉 & 87 & 16 & 18.4 & $63.1 \pm 2.5 \mathrm{c}$ & $11.6 \pm 0.5 \mathrm{~b}$ & 2 & 12.5 \\
\hline & 人工受粉 & 61 & 39 & 63.9 & $34.1 \pm 2.4 \mathrm{ab}$ & $21.7 \pm 1.5 \mathrm{c}$ & 1 & 2.6 \\
\hline \multirow{2}{*}{2011} & 自然受粉 & 117 & 50 & 42.7 & $25.1 \pm 6.0 \mathrm{a}$ & $9.4 \pm 2.3 \mathrm{~b}$ & 20 & 40.0 \\
\hline & 人工受粉 & 45 & 19 & 42.2 & $32.5 \pm 8.3 \mathrm{ab}$ & $14.4 \pm 3.7 \mathrm{~b}$ & 6 & 31.6 \\
\hline $\mathrm{t}$ 検定 & $\begin{array}{l}\text { 自然受粉 } \\
\text { 人工受粉 }\end{array}$ & & & $\mathrm{ns}^{\mathrm{r}}$ & & & & ns \\
\hline
\end{tabular}

z 肥大したさく果が結実した株数

y 供試株数のうち，さく果が結実した株の割合

$\mathrm{x}$ 結実したさく果の種子発芽率 $(\mathrm{n}=10)$

w供試自生地で生育するサギソウ 1 株当たりが形成する生育可能な種子の割合（ $\mathrm{w}=\mathrm{y} \times \mathrm{x} / 100 ）$

vさく果結実株のうち, 昆虫の食害跡や産卵跡とみられる穴などの虫害が認められるさく果結実株の数

uさく果結実株数のうち，被虫害さく果結実株数の割合（ $\mathrm{u}=\mathrm{y} / \mathrm{z} \times 100 ）$

$\mathrm{t}$ 平均值土標準誤差

s Tukey の多重比較検定により異なる文字間には 5\%水準で有意差あり

r 2011 年， 2012 年拈よび 2015 年の自然受粉と人工受粉間で，ns は 5\%水準で有意差がないことを示す 
第 2 表 ‘作手’ 系サギソウの異なる生育地における自然受粉 によるさく果結実株率

\begin{tabular}{cccc}
\hline \hline 生育地 & 試験区 & 供試株数 $^{\mathrm{z}}$ & さく果結実株率 $\mathrm{y}(\%)$ \\
\hline 愛知県 & 供試自生地 & 321 & $23.2 \pm 10.0^{\mathrm{x}} \mathrm{a}^{\mathrm{w}}$ \\
愛知県 & ${\text { 自生地 } \mathrm{A}^{\mathrm{v}}}$ & 188 & $19.1 \pm 8.1 \mathrm{a}$ \\
東京都 & 栽培地 $^{\mathrm{u}}$ & 252 & $46.9 \pm 7.5 \mathrm{~b}$ \\
\hline
\end{tabular}

${ }^{\mathrm{z}} 2011$ 年, 2012 年および 2015 年の供試株数の合計

yさく果が結実した株数の割合

$\mathrm{x}$ 平均值士標準誤差 $(\mathrm{n}=3)$

${ }^{\mathrm{w}}$ Tukey の多重比較検定により異なる文字間には $5 \%$ 水準で 有意差あり

$\mathrm{v}$ 供試自生地から約 $3 \mathrm{~km}$ 離れた自生地

$\mathrm{u}$ 東京都立園芸高等学校草花戋場

第 3 表 サギソウの系統別発芽率

\begin{tabular}{cl}
\hline \hline 系統 & 発芽率 $(\%)$ \\
\hline 作手 & $61.1 \pm 5.4^{\mathrm{z}} \mathrm{a}^{\mathrm{y}}$ \\
青雲 & $60.5 \pm 4.3 \mathrm{a}$ \\
武蔵野 & $70.9 \pm 3.7 \mathrm{a}$ \\
白河 & $70.3 \pm 4.4 \mathrm{a}$
\end{tabular}

$\mathrm{z}$ 平均值 \pm 標準誤差 $(\mathrm{n}=3)$

y Tukey の多重比較検定により同一文字間には 5\%水準で有 意差なし

手’系, ‘武蔵野’ 系, “白河’ 系抒よび ‘青雲’ 系には差が 認められなかった。このことから，“作手”系は他の系統と 比較して発芽率が低くなる特性は認められなかった。

\section{4. サギソウ種子発芽率に及ぼす施肥の影響（実験 4）}

種子の発芽率に生育時の栄養状態が影響するかどらか を調查し，結果を第 4 表に示した。 供試した球根は，無 施肥由来の球根重よりも施肥由来の球根重が重く, 肥大し ていた。無施肥区抢よび施肥区ともにさく果は形成された が，さく果の肥大は貧弱なものが多かった．無施肥区およ び施肥区ともに発芽率が低く，両区間には差が認められな かった。

さらに，1株に 2 さく果が形成されていた 8 株のさく果 形成位置ごとの種子発芽率を第 5 表に示した。栄養条件が 同じ 1 株に形成された $2 さ く$ 果の種子発芽率を比較すると,
第 5 表 自生地で結実した 1 株 2 さく果の種子発芽率

\begin{tabular}{|c|c|c|c|}
\hline $\begin{array}{l}\text { 供試株 } \\
\text { No. }\end{array}$ & $\begin{array}{c}\text { さく果 } \\
\text { 形成位置 }\end{array}$ & $\begin{array}{c}\text { 種子発芽率 } \\
(\%)\end{array}$ & $t$ 検定 ${ }^{x}$ \\
\hline \multirow[b]{2}{*}{1} & 上部 & $37.8 \pm 2.1^{\mathrm{y}}$ & \multirow{2}{*}{$*$} \\
\hline & 下部 & $27.7 \pm 2.4$ & \\
\hline \multirow[b]{2}{*}{2} & 上部 & $55.0 \pm 4.1$ & \multirow[b]{2}{*}{ ns } \\
\hline & 下部 & $54.3 \pm 4.0$ & \\
\hline \multirow{2}{*}{3} & 上部 & $22.8 \pm 2.3$ & \multirow{2}{*}{$*$} \\
\hline & 下部 & $52.0 \pm 1.3$ & \\
\hline \multirow{2}{*}{4} & 上部 & $34.5 \pm 2.5$ & \multirow{2}{*}{ ns } \\
\hline & 下部 & $43.2 \pm 3.1$ & \\
\hline \multirow{2}{*}{5} & 上部 & $39.3 \pm 4.2$ & \multirow{2}{*}{$*$} \\
\hline & 下部 & $71.5 \pm 3.0$ & \\
\hline \multirow[b]{2}{*}{6} & 上部 & $74.3 \pm 1.3$ & \multirow{2}{*}{$*$} \\
\hline & 下部 & $39.3 \pm 1.3$ & \\
\hline \multirow[b]{2}{*}{7} & 上部 & $39.4 \pm 2.8$ & \multirow{2}{*}{$*$} \\
\hline & 下部 & $59.6 \pm 5.1$ & \\
\hline \multirow{2}{*}{8} & 上部 & $60.7 \pm 4.2$ & \multirow{2}{*}{$*$} \\
\hline & 下部 & $12.5 \pm 1.1$ & \\
\hline
\end{tabular}

$\mathrm{z}$ 下部は第 1 花を人工受粉し，上部は第 2 花が自然受粉

$\mathrm{y}$ 平均值士標準䛊差 $(\mathrm{n}=5)$

x*は 5\%水準で有意差あり, ns は有意差なしを示す

差が認められなかったのは2株のみで，他の6 株の種子発 芽率には差が認められた。また，種子の形成位置による明 確な差は認められなかった。

\section{5. 受粉時の開花後日数ごとの種子発芽率（実験 5)}

開花後から日数を変えて人工受粉し，それ杂れの受粉日 数区ごとに形成されたさく果の中で，よく肥大して充実し たさく果の結実株率を第 6 表に，種子発芽率を第 1 図に示 した.さく果結実株率は開花後 $1 \sim 7$ 日目までに受粉した 株では差が認められなかったが，8～9 日目に受粉した株 では低くなった。一方，開花後 $4 \sim 5$ 日目に受粉して形成 されたさく果の種子発芽率は, 他の受粉日数区に比べて有 意に高くなった。

第 4 表 種子発芽率に及ぼす施肥の影響（人工受粉）

\begin{tabular}{|c|c|c|c|c|c|c|}
\hline 処理区 & $\begin{array}{c}\text { 供試 } \\
\text { 球根数 }\end{array}$ & $\begin{array}{c}\text { 供試 } \\
\text { 球根重 } \\
(\mathrm{g})\end{array}$ & $\begin{array}{l}\text { 受粉 } \\
\text { 株数 }\end{array}$ & $\begin{array}{c}\text { さく果 } \\
\text { 結実株数 }\end{array}$ & $\begin{array}{c}\text { さく果 } \\
\text { 結実株率 } \mathrm{z} \\
(\%)\end{array}$ & $\begin{array}{c}\text { 種子 } \\
\text { 発芽率y } \\
(\%)\end{array}$ \\
\hline 無施肥区 & 30 & $0.41 \pm 0.02^{\mathrm{x}}$ & 30 & 20 & 66.7 & $25.0 \pm 2.3$ \\
\hline 施肥区 & 30 & $0.72 \pm 0.06$ & 30 & 21 & 70.0 & $25.2 \pm 3.2$ \\
\hline $\begin{array}{c}\text { 無施肥区 } \\
\text { 施肥区 }\end{array}$ & & $*$ & & & & ns \\
\hline
\end{tabular}

\footnotetext{
zさく果が肥大して結実した株数

${ }^{\mathrm{y}} \mathrm{n}=20$

$\mathrm{x}$ 平均值士標準䛊差 $(\mathrm{n}=30)$

${ }^{\mathrm{w}} 5 \%$ 水準で*は有意差があり, ns は有意差がないことを示す
} 


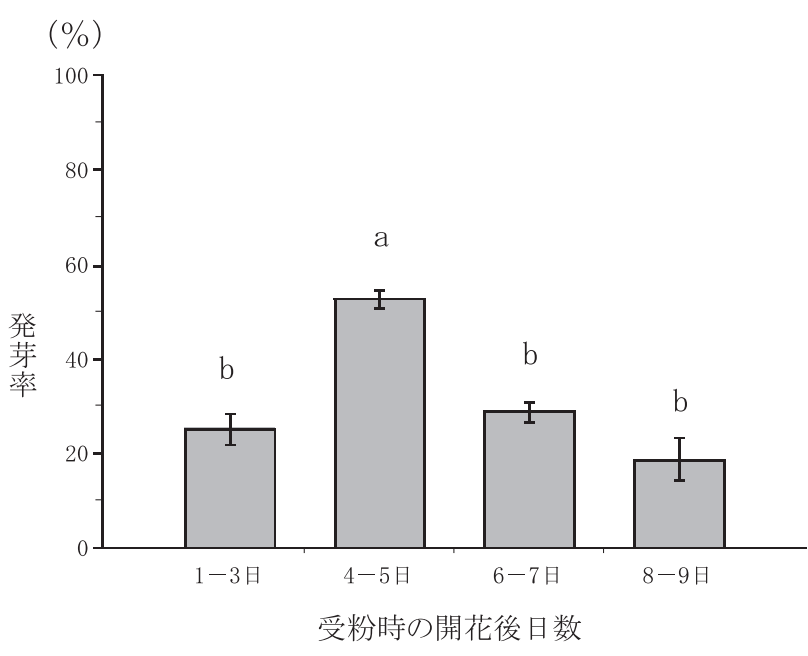

第 1 図 受粉時の開花後日数ごとの種子発芽率

Tukey の多重比較検定により異なる文字間には 5\%水準 で有意差あり

縦線は標準誤差を示す $(n=10)$

第 6 表 ‘作手’ 系サギソウの異なる開花後日数ごとの人工受 粉によるさく果結実株率

\begin{tabular}{ccc}
\hline \hline 開花後の受粉日数 & 供試株数 $^{\mathrm{z}}$ & さく果結実株率 ${ }^{\mathrm{y}}(\%)$ \\
\hline 1 日目 $\sim 3$ 日目 & 106 & $28.7 \pm 1.6^{\mathrm{x}} \mathrm{ab}^{\mathrm{w}}$ \\
4 日目 $\sim 5$ 日目 & 59 & $62.2 \pm 10.5 \mathrm{a}$ \\
6 日目 $\sim 7$ 日目 & 53 & $27.7 \pm 8.1 \mathrm{ab}$ \\
8 日目 $\sim 9$ 日目 & 31 & $15.9 \pm 0.8 \mathrm{~b}$
\end{tabular}

z 2012 年, 2013 年および 2015 年に 1 株 1 花で受粉した供試 株数の合計

$\mathrm{y}$ 供試株数に対するさく果結実株数の割合

$\mathrm{x}$ 平均值 \pm 標準詋差

${ }^{\mathrm{w}}$ Tukey の多重比較検定により異なる文字間には 5\%水準で 有意差あり

\section{考察}

サギソウは細長い距により長い口吻を持つスズメガ類に 適応している. スズメガはガ類の中で口吻の長さが特に長 く, サギソウの距の長さとサギソウを訪花するスズメガの 口吻の長さは医葟一致している。茂田ら（2004）はサギソ ウの受粉を媒介する昆虫について調査したところ, 形態的 な適応関係がみられるスズメガの他に, 適応関係が見られ ないアザミウマ類の種子生産への貢献（受粉）が $26 \%$ も の割合で認められたことを報告している。 アザミウマ類は 花や子房，葉などを吸汁・食害することが知られている. 従って, サギソウのさく果の虫害にはアザミウマ類による 吸汁・食害も含まれると考えられ，被虫害果の割合が高い ほどアザミウマ類の生息数が多かったと推察される. サギ ソウ自生地に扣いてアザミウマ類の生息数が多くなるほ ぞ，さく果結実株率は高くなると考えられる.

第 1 表の 2015 年, 2012 年, および 2011 年の順に自然受 粉区のさく果結実株率が高くなり, 被虫害さく果結実株率
も同様の傾向が認められことや, 第 2 表で供試自生地, 自 生地 $\mathrm{A}$ 括よび東京都内の栽培地ごとに, 自然受粉による さく果結実株率を比較した結果から，さく果結実株率には 気温, 日射量, 降雨などの生育地の条件とともに, 訪花昆 虫数の関与も示唆された。

次に，第 1 表の自然受粉区拈よび人工受粉区で結実した さく果の種子発芽率は概して 50\%よりも低い傾向が認め られたので, これが ‘作手”系サギyウ特有の性質による ものなのかどらかを調べるために，他の種々のサギソウ系 統の種子発芽率と比較した（第3 表）結果, ‘作手’ 系の種 子発芽率は他の系統の種子発芽率と差が認められなかった ことから，自然受粉区拈よび人工受粉区で結実したさく果 の種子発芽率が低くなったのは，“作手’ 系サギソウの特性 ではなく，他の要因によるものであると考えられた。

種子発芽率に影響する要因を探るために，サギソウ個体 の栄養条件が，形成される種子の発芽率に影響を及ぼすか ぞらかを調査した（第 4 表）、その結果，栄養条件の違い は種子の発芽率に全く影響しないことが明らかとなった。 さらに，栄養条件が同じ 1 株に形成された上部，下部の 2 さく果の種子発芽率（第 5 表）を比較すると，75\%の株に 差が認められ，栄養条件が種子発芽率に影響するとは考兄 られなかった。な扣，上部と下部間では種子発芽率に一定 の傾向は見られなかった,

そこで，受粉時の開花後日数の違いが，さく果結実率と 種子発芽率に影響を及ぼすかどらかを第 6 表および第 1 図 で検討したところ，開花後 4～5 日目の開花中期に受粉す ると，形成されるさく果の結実率も良好となり，種子発芽 率も高くなることが明らかとなった. ラン科植物の受粉適 期は種類によって異なることが知られており（岡見， 1964)，サギソウでは開花後 4～5 日目に生理的受粉態勢 が最も整らものと考光られた.

供試自生地の自然受粉区で形成されたさく果結実株率と 種子発芽率をみると, 被虫害さく果結実株数が多かった 2011 年はサギソウ開花初期（開花後 1～3 日目）の花が受 粉したと推察され，さく果結実株率は $42.7 \%$ と他年次より も相対的に高くなったものの，種子発芽率は $25.1 \%$ と他年 次に比べて低くなったと推察された。2012年および 2015 年のさく果結実株率が 2011 年に比べて急激に低下したの は, 被虫害さく果株数が 2011 年に比べてかなり減少した ことから，訪花昆虫数の関与が示唆された。 2012 年抒よ び 2015 年の種子発芽率をみると, 2011 年よりも高くなっ たことから，開花後 4 日目〜 5 日目の受粉適期前後に訪花 昆虫が受粉を媒介したことによるものと推察された。

一方，供試自生地の人工受粉区で形成されたさく果結実 株率と種子発芽率は，開花後日数の異なる花が混在する自 生地で，ある特定の日に一斉に人工受粉したために，さく 果結実株率と種子発芽率は年次によりばらつきが大きく なったと推察された.

供試自生地に打ける自然受粉区の実生率は $11.6 \%$ 
$3.6 \%$ であり，1さく果内に形成される種子数は約 3000 粒 （木村，1980）とすると，1株の個体が形成する実生生育可 能な種子数は約 350 粒〜 110 粒となる. 高橋ら（2005）は 発芽したサギソウプロトコームにサギソウの生育を促進 するラン菌を感染させないで直接サギソウ自生地に播種し たところ，実生生育するプロトコームの割合はわずかに $0.52 \%$ にすぎなかった。 このことから, サギソウの生育を 促進するラン菌が生息する自生地で自然受粉により形成 された種子が実生生育する個体数は 1 株当たり 1.82 個体 （350 粒 $\times 0.52 / 100 ） \sim 0.57$ 個体（110 粒 $\times 0.52 / 100 ）$ にす ぎず，自生地において実生生育が期待できる個体数はきわ めて少ないことが推察された。

以上のことから，サギソウの当該自生地に扣いて自然受 粉により形成されたサギソウ種子の特性として，(1)形成さ れるさく果の結実率执よび種子発芽率は株の栄養状態には 影響されないこと, (2)形成されるさく果の結実株率および 種子発芽率は年次により変動し, 受粉時の開花後日数の影 響と, 訪花昆虫数の関与が考えられること, (3)当該自生地 に执いて実生生育が期待される個体数は 1 株当たり 1.82 個 体〜 0.57 個体にすぎず，きわめて少ないと推察されるこ とである。

供試自生地に打ける実生率は，人工受粉区では自然受粉 区の 1.5 倍〜 7.7 倍となったことから，衰退した自生地に 扣いて実生個体を増加させる一方法として, 人工受粉は有 効であると考えられた。

\section{摘 要}

サギソウが自生地で実生から生育するには，昆虫により 受粉し (自然受粉)，多くの種子が形成されることが必要 である。そこで，愛知県内のあるサギソウ自生地を供試自 生地とし，自然受粉による種子形成状況を調査したとこ ろ, 自生地で形成されるサギソウのさく果結実率と種子発 芽率は年次によって変動した。この要因を検討したとこ ろ，サギソウの栄養状態が種子発芽率に及ぼす影響は認め られず，供試自生地に飛来する媒介昆虫の関与が推察され
た. また，受粉時の開花後日数によって形成されるさく果 の結実率抢よび種子の発芽率は大きく異なることが明らか となり，開花後 4～5 日目の開花中期に受粉して形成され たさく果の結実率と種子の発芽率が高くなった。このこと から，サギソウは開花後 $4 \sim 5$ 日目に最も生理的受粉態勢 が整い，この時期に昆虫が受粉を媒介して形成されたさく 果の種子発芽率は高くなることが示唆された.

\section{引用文献}

古川仁朗・小野道之・鎌田 溥 - 國武久登・柴田大輔・中 野 優・三位正洋・石橋正美・岩堀勝弥・岡田雄治・ 栗原宏泰・高橋和彦・高橋晋太郎・安田博武. 2013. 図解植物バイオテクノロジ一教授用指導書. p. 43-44. 実教出版株式会社. 東京.

唐澤耕司. 1996. 蘭. p.9. 山と渓谷社. 東京.

木村なほ. 1980. サギソウの観察と栽培. p. 14. ニュー・ サイエンス社. 東京.

岡見義男. 1964. ラン 種類と培養. p. 90 . 誠文堂新光 社. 東京.

茂田幸嗣・井鷺裕司・中越信和. 2004. 形態的にスズメガ 蝶に特化したサギソウ（ラン科）に打けるアザミウマ の種子生産への貢献. 日本生態学会第 51 回全国大会 ポスター発表. 01-w08.

高橋和彦・秦名俊光・石川 林・荻原 勲. 2012. 自生地 のラン菌根菌を接種したゲル被覆サギソウプロトコー ム設置法によるサギソウの実生育成. 園学研. 11 : 213-217.

高橋和彦・石川林・荻野崇義・秦名俊光 - 荻原 勲. 2008．自生地に扣けるサギソウ種子の発芽，菌の感染 時期掞よび菌根菌接種サギソウプロトコームの好適設 置時期. 園学研. 7:27-31.

高橋和彦・熊谷 寛・石川 林・荻原 勲. 2005. ラン菌 根菌を接種したゲル被覆サギソウプロトコームによる サギソウの実生育成执よび自生地に沶ける生育. 園学 研. 4: 397-400. 